\title{
Web-based discussions in teaching and learning: Secondary school teachers' and students' perception and potentiality to enhance students' performance in organic chemistry
}

\author{
Aloys lyamuremye ${ }^{1} \cdot$ Janvier Mukiza ${ }^{1,2} \cdot$ Ezechiel Nsabayezu$^{1}$. \\ Fidele Ukobizaba ${ }^{1} \cdot$ Kizito Ndihokubwayo $^{1}$
}

Received: 13 July 2021 / Accepted: 19 August 2021/ Published online: 28 August 2021

(c) The Author(s), under exclusive licence to Springer Science+Business Media, LLC, part of Springer Nature 2021

\begin{abstract}
The current work explores the secondary school teachers' and students' perception on web-based discussions in teaching and learning and its potentiality to enhance students' performance in organic chemistry. A mixed approaches typically interviews and achievement tests were applied for collecting qualitative and quantitative data respectively for triangulation purpose. A total of 138 senior five students and 4 teachers were purposively selected from the two secondary schools at Kicukiro District in Kigali city, Rwanda. Discourse and interpretive approaches were used to analyze qualitative data, while t-test was used for analyzing quantitative data obtained from pre- and post-test scores. The results from this study revealed that applying web-based discussions is the teaching method that potentially and effectively enhances students' performance in organic chemistry with 0.10 learning gains and an effect size of 0.43 ( $\mathrm{df}=137$ and $p<.05)$. In addition, students and teachers have been expressed positive perceptions to the application of web-based discussions in teaching and learning. Therefore, teachers and students are recommended to access a universal chemistry network and conduct web-based discussions for increasing students performance in organic chemistry.
\end{abstract}

Keywords Students' perception and performance - Teaching and learning · Organic chemistry $\cdot$ Web-based discussions

Janvier Mukiza

janvier.mukiza@gmail.com

Extended author information available on the last page of the article 


\section{Introduction}

Discussion is a collaborative exchange of ideas between a teacher and students or between students themselves for the purpose of furthering students thinking, learning, and problem-solving (Wilkinson, 2016). Nowadays, there is a fast expansion of the utilization of the internet and digital resources, whereby the web has become the most interactive tool and medium of communication in teaching and learning process (Epignosis, 2014). The web-based discussions is a form of learning through networking and provides the opportunities for students to gain and share information themselves as well as with their teachers (Nor et al., 2010). Internet is considered as one of the worldwide broadcasting capabilities for sharing information and collaboration, and it is used for interaction between individuals regardless of their geographic location (Dogruer et al., 2011). It was found that web-based discussion builds upon the community of inquiry model. This model assumes that the knowledge is constructed from the interaction between cognitive presence, teaching presence and social presence (Swan, Garrison, \& Richardson, 2009). Cognitive presence refers to how learners confirm and construct their understanding through reflection and discourse (Garrison, 2018).

Chemistry is considered a difficult subject for learners (Johnstone, 2000). Due to its teaching methodology, organic chemistry is one of the topics in chemistry that is difficult to learners (Ochonogor, 2020). Different studies revealed that there are persistent problems about how organic chemistry is taught and showed that those problems need urgent interventions (O’Dwyer \& Childs, 2017). Different authors highlighted some topics that are difficult to learn in organic chemistry, including drawing and representation of organic compounds (Johnstone, 2006), properties of organic compounds (Anderson \& Bodner, 2008), aromaticity (Rushton et al., 2008), reaction types (Ferguson \& Bodner, 2008), and reaction mechanisms (Ferguson \& Bodner, 2008). According to Lorenzo et al. (2012), the synthesis, instrumentation, structure, properties, organic mechanism, nomenclature, isomerism, drawing and classification of organic compounds and organic reaction are challenging topics for both teachers and students in organic chemistry. Organic chemistry is a subject that requires thinking and high cognitive demand (Ahmad, Samara, \& Development, 2016) during its teaching and learning. Research showed that the secondary school education focuses on memorization in the most of developing countries, (Shana, 2015). Nowadays, web-based learning (WBL) has become a great educational resource whereby students access online information, collaborate with their peers and teachers without restrictions of time and environment (Poon et al., 2004).

This study is guided by social constructivist theory. Vygotsky's theory proposes that progress depends on the interface between individuals and the materials that the culture offers to help form their own view of the domain (Zhou \& Brown, 2014). According to this theory, cultural tools pass from one person to another through three means typically, imitating or reproducing, instruction by the teacher and use this instruction by self-learning and collaborative learning (Tomasello, 2016).

Web-based discussion is expected to be one of the suitable methodologies for teaching organic chemistry since it offers the potential flexibility and facilitates, 
interactions between students themselves as well as students with their teachers (Sanderson \& Field, 2018). Teaching organic chemistry in Rwandan secondary schools uses different approaches, including group discussions, practical works, individual and group research as well as field visits. On the other hand, the utilization of web-based teaching and learning in Rwandan secondary schools is still at an early stage of development even though most of institutions in Rwanda adopted e-learning to instruct their students especially in this period of covid19 pendemic disease. Some institutions have platforms where students are supposed to interact and discuss through e-learning, but the resources are exhausted (Uwamahoro et al., 2021), and the majority of those platforms are not actively facilitated, and most of them are not operational (Umurerwa, 2016).

In the study conducted by Nsengimana et al. (2021) on the communication platforms, ICT infrastructures and software, and online resources were found as opportunities for online teaching and learning. Therefore, there is a need to examine the effectiveness of web-based discussions in relation to the students' cognition and perception and see how this learning approach can enhance students' performance in organic chemistry. The current study aimed at secondary school teachers' and students' perception on web-based discussions in teaching and learning. The study intends also to investigate if there is a potential influence of web-based discussions on students' performance in organic chemistry.

\section{Research questions and hypothesis}

The current study is based on the following research questions:

1. How is students' and teachers' perceptions towards the utilization of web-based discussions in teaching and learning?

2. Does it exist any relationship between web-based discussions and students' performance in organic chemistry?

Therefore, we hypothesize that:

H0: There is no relationship between web-based discussions and students' performance in organic chemistry.

H1: There is a relationship between web-based discussions and students' performance in organic chemistry.

\section{Methodology}

In this study, both interview and achievement tests were used for data collection. The target population of the study was all senior five chemistry students from the two selected secondary schools in Kicukiro District located in Kigali city in Rwanda. These schools were selected due to the purpose of the study and availability of 
computer lab and internet connection. For students doing sciences in secondary schools, organic chemistry is taught in senior five. For this purpose, one senior five classrooms was selected in each school, and a total of 138 participants comprising 83 males and 55 females were involved in the study. After teaching students with physical contact, a pretest was administered and additional web-based discussions have been done for a period of one month. Thus, this is one group pre- and posttest design and it is appropriate among quasi experimental designs according to (Fraenkel et al., 2012). An interview was used to collect both qualitative data in which participants responded to the research questions. Additionally, quantitative data were collected through interviews responding to the second research question.

The authors in close collaboration with a team of technicians have designed and developed a web-based discussion forum called Universal Chemistry Network (UCN) available at www.universalchemistrynetwork.com (see the Fig. 1).

Every student was registered to the forum in order to get access, and he/she was required to login to his/ her account by using his/ her own username and password. The Fig. 2 shown below shows how students and teachers logged in to the designed web-based discussion platform.

After being logged in, every student was able to create or comment on the given organic chemistry topic in the created discussion room. The Fig. 3 below shows the discussion room of the designed web-based discussion.

Before the introduction of the new teaching method (web-based discussion), all students and teachers from the selected schools were trained about the utilization of the designed web-based discussion platform. All students did a pre-test composed of 20 multiple choice questions (see Appendix) before the introduction of the designed webbased discussion. Thereafter, the selected ten topics of organic chemistry have been discussed via the designed web-based discussion platform. The discussed topics were

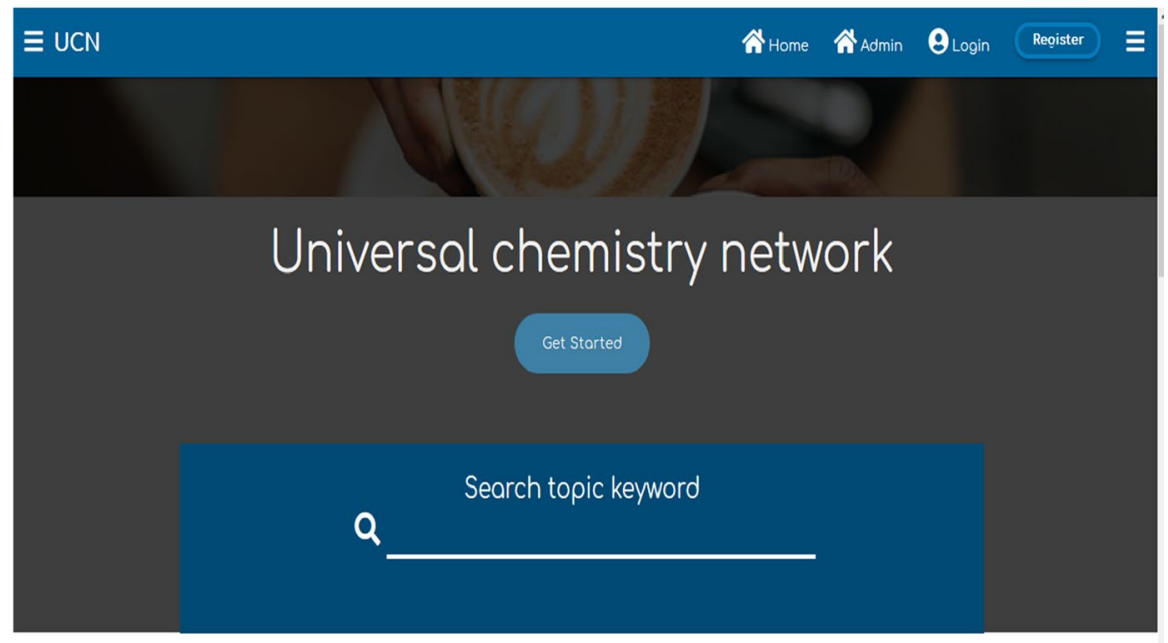

The forum

Fig. 1 Home page of the designed web-based discussion forum 


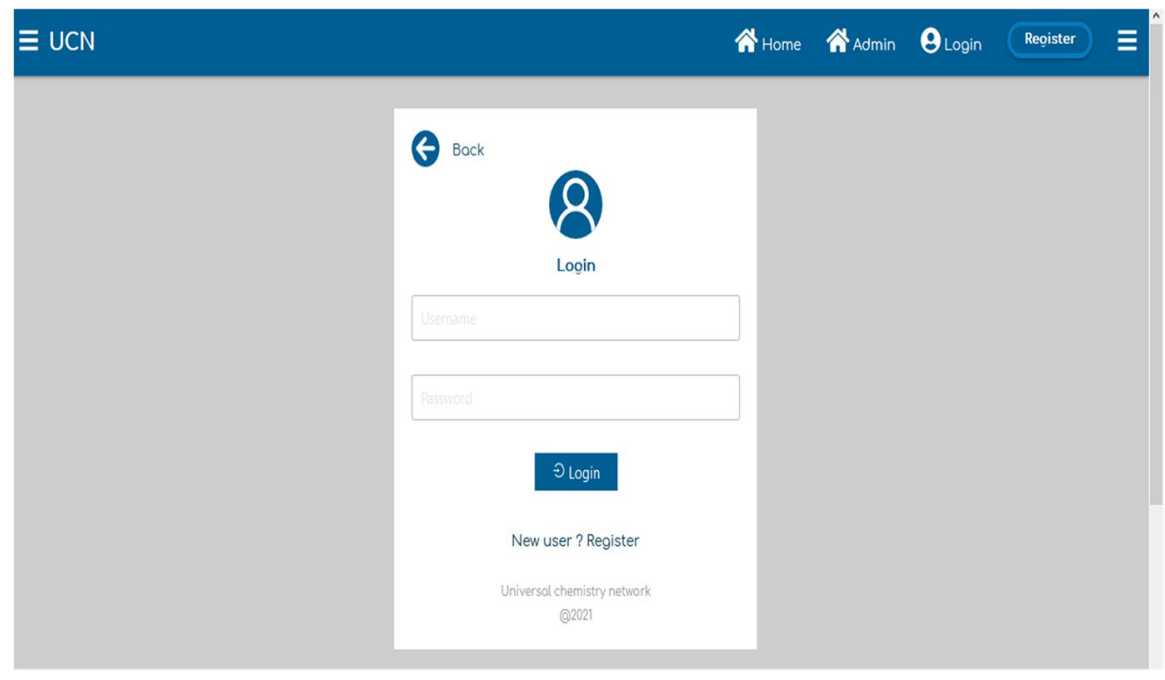

Fig. 2 Status of login window to the designed web-based discussion platform

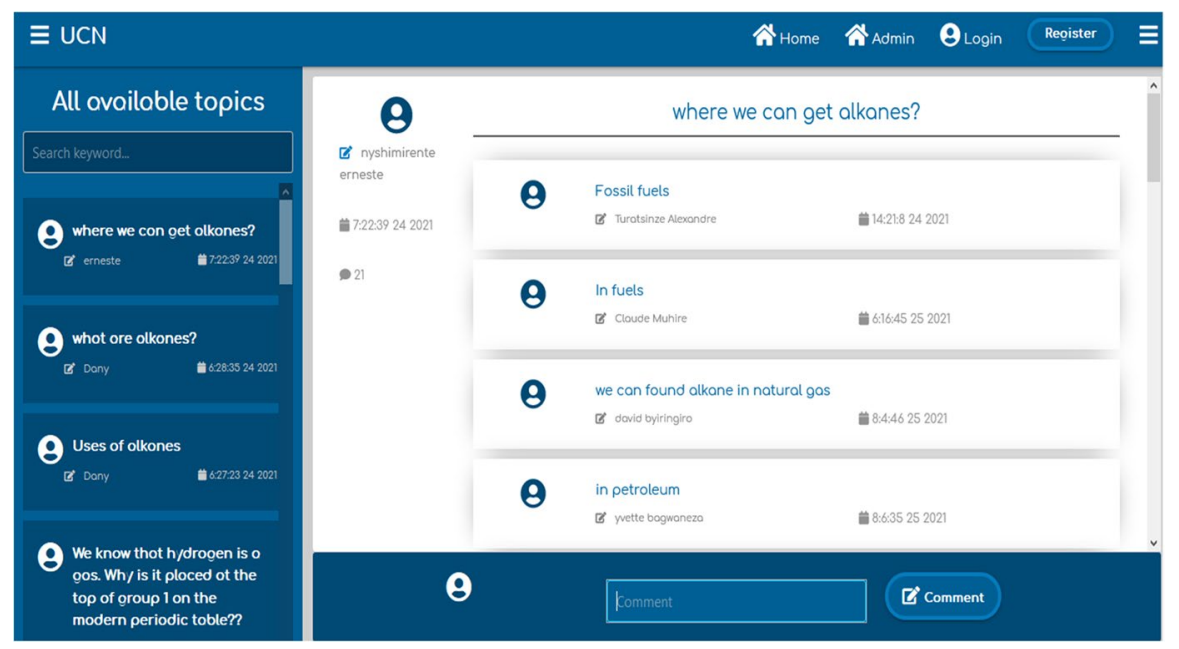

Fig. 3 Discussion of students via $\mathrm{UCN}$

based on alkanes, alkene, alkyne, alcohols, aldehyde, ketone, ethers, esters, carboxylic acids and amines, and the content discussed was mainly based on the nomenclature, physical and chemical properties, and preparation of these organic compounds. Afterward, all students did a post-test composed by 20 multiple choice questions, which were the same as the pre-test questions (see Appendix). Among 138 senior five chemistry students, 40 students (20 males and 20 females) have been purposively selected for interview. An equal number of boys and girls increases the visibility and gender balance. The interview was also composed of four senior five chemistry teachers. These 
teachers were selected because they were used as facilitators of the researcher during the discussion and they were also selected to explore their perceptions about the use of web-based discussions in teaching and learning organic chemistry.

Both pre-and post-test were marked out of twenty scores. These tests aimed at investigating the effectiveness and potentiality of web-based discussions (WBD) to enhance students' performance in organic chemistry. The interview was composed by ten open questions investigating student's perceptions of the effectiveness of WBD in teaching and learning and the challenges experienced while using WBD in learning organic chemistry. Pre-and post-test results were analyzed by using descriptive statistics such as mean, standard deviation, maximum, minimum, and range as well as inferential statistics such as t-test of the mean difference between two groups of students to check if there exists an influence of web-based discussion on academic performance using statistics package for social Studies (SPSS). Data from interview were analyzed using interpretive, discourse and ground theory-based analysis (Starks, 2008) to reveal students' and teachers' perceptions about the usefulness of WBD in teaching and learning.

Validity of the instruments refers to the measure of what is supposed to measure (Bashir et al., 2008). To ensures the content validity, the research instruments, the interview were checked and approved by a team of experts in research and chemistry education from the College of Education of the University of Rwanda (UR-CE). The recommendations and comments provided were very helpful and constructive to improve the final research instruments. Reliability is concerned with the consistency, stability, and repeatability of the results (Hayashi et al., 2019). To ensure reliability of this study, a pilot study was conducted in one school (different from the schools involved in this study) with the same characteristics of the schools under the study. In addition, to ensure the internal consistency of tests and how the test items contribute to the construct being measured. The reliability coefficient was calculated by using the Split-Half Reliability method. Within this regard, we formed two homogeneous groups of students under the pilot. Then, we separated the test items into two halves. One group did odd questions, and another did even questions. We calculated the correlation coefficient (reliability coefficient) between the two groups, and was found to be 0.755 , which is high correlation coefficient reflecting high consistency of the results from both groups of students. The observed correlation coefficient reflects that the same results would have been found upon calculation of correlation coefficient between two groups of questions answered by the same group of students. The participants were explained the aim of the study, before signing the consent forms for a willing participation in the study. All the participants were 16 years and above and we have been ensured that the principle of anonymity is respected in order to guarantee the confidentiality of the collected information.

\section{Significance of the study}

This study focuses on the cognitive presence of learners in web-based discussions in teaching and learning organic chemistry. This is important to learners for developing their competencies and skills needed for labour market as the Rwandan curriculum 
envisages (REB, 2015a). Students' familiarity with the utilization of web-based resources will help them to solve real-life problems and developing $21^{\text {st }}$ century skills. Those skills include critical thinking, problem-solving, creativity and innovation, analytical skills, collaboration as well as communication skills (Bialik et al., 2015; REB, 2015a). Krasnova and Ananjev (2015) highlighted that developing interpersonal skills through online collaboration is an integral part of the preparation for their future career. In addition, this will help chemistry students and teachers to collaborate with each other from different schools in Rwanda, Africa, and all over the world. According to Rwanda Basic Education Board (REB) (REB, 2019), a good educational system should produce graduates responding to the need of the labor market; to achieve this, employees must have the technical and competencies needed in labor market. This study will also help the Ministry of Education (MINEDUC), REB, and school administrators to solve the problems of instructional resources and reduce the cost of printing textbooks. The result from this work will also help the researchers to gain insight, experience, familiarity, and effectiveness of web-based discussion forum, which will help them to design an online platform where students from Rwanda secondary schools and global chemistry students, chemistry teachers will collaborate and discuss chemistry concepts.

\section{Results and discussions}

\subsection{Students' perceptions towards the utilization of web-based discussion}

To explore student's perception, experience, and familiarity via web-based discussion in teaching and learning organic chemistry, the following questions (see Box 1) were used during interview.

All interviewed students agreed that it was not the first time using the internet to collaborate with others. Students reported that they used the internet to collaborate with others on Facebook, WhatsApp, email, Twitter, Instagram and Snapchat. Most of the students (75\%) argued that they used the internet in their learning while they are out of the classroom setting. Only $25 \%$ of interviewed students argued that it was

Box 1: Interview guide

- Collaborative learning refers to learning in small groups toward a common goal. Did you get an opportunity to exchange ideas and engage in discussion in the classroom?How?

- Web-based discussion is the online interactive collaboration on the basis of a virtual simulation or special Learning Management System for better conversation. Is this the first time that you use online collaboration in the classroom?If yes, how many online courses have you taken?

- Did your prior experience of using web-based discussion (WBD) forums make your learning experience easier or more difficult? Do you think your prior knowledge of using the internet had helped you become a more critical thinker? Please explain.

- Would you consider web-based discussion experiences positive in your course of organic chemistry?

- Have you discussed with your colleagues from other combinations about this kind of learning? How did others from other groups think about this kind of collaboration (Web-Based Discussion)? 
the first time they used the internet to collaborate with others in the classroom. However, the students reported that having prior knowledge on the use of the internet has a positive impact on the utilization of Web-based discussion. One of the interviewed students said: "I used internet connection before, and I had an experience on the utilization of the internet. This experience helped me to collaborate with others in learning chemistry and other subjects."

As it was observed, the integration of web-based discussion at the first day, students were not familiar to this kind of discussion. Students' participation was low and there was a small number of comments on the provided post. Later, students became familiar and experienced to web-based discussion as time was going on, and they were motivated and free to post their comments related to the topic under discussion. Students became experienced towards the utilization of web-based discussion in teaching and learning organic chemistry. As it was revealed by one student: "A web-based discussion provides additional resources to search additional information as we were connected to the internet." These results are in accordance with the findings of Onyema et al. (2019) which indicated that the using of online discussions enhances students' motivation, confidence, and free expression of their views and ideas. Having access to several opinions and resources can inspire students to show more interest and commitment to class activities. Web-based discussion through internet use during the discussion can epitomize an essential source of additional information. However, our specific finding was that many students were already using trending social media platforms such as Twitter, Instagram, and Snapchat. This might be caused by the fact that participant students were from Kigali city, and we encourage future studies to confirm with students in rural parts of Rwanda.

\subsection{Indicators of web-based discussions to solve learner's problems in organic chemistry}

To explore and understand the indicators of web-based discussion that help students solve problems in organic chemistry, the following research question guided researchers: What are indicators of web-based discussion forum for solving learner's problems in organic chemistry?

The students reported some indicators of web-based discussion that solve learner's problems in organic chemistry, including number of messages, quality of topics, number of students who participated during the discussion, comments from students, and feedback from teachers. It was also reported that the number of created topics and experiences of teachers and students have a positive influence on students' understanding. During interaction via web-based discussions, learners received, created, and shared information with their fellow students and teachers. Knowledge was built through interactive online collaboration and discussions. This was similar to the research of Graham (2015) which proved that the behavioral indicators, such as the number of logins, number of questions asked, lectures taken, number of posting, and times that they participated online discussions increase students' progress. According to Lee et al., (2019), active and self-directed learning 
activities as an independent learning environment are an important factor that supports online collaborative learning.

\subsection{Knowledge gain through web-based discussion strategy in teaching and learning organic chemistry}

After interactions via UCN, 40 students were interviewed and asked about their perceptions about the added value of web-based discussion learning. Figure 4 below shows the discussion of students and researchers via the designed web-based discussion.

From the interview conducted with students, all students agreed that a web-based discussion is an effective tool for collaboration because it provides an opportunity for students and teachers to search for additional information, share ideas, knowledge, and experiences. For instance, one student said: "A web-based discussion provides additional resources to search additional information as we were connected to the internet." Another student also said: "I got a full opportunity to exchange ideas with my colleagues and my teacher". Students reported that the WBD provides a good experience and impression in learning organic chemistry. All students reported that knowledge is constructed as the result of interaction between students, teachers, and the internet. For instance, one student said: "I have constructed my knowledge and skills from the comments of others." Indeed, the use of a web-based technology provides a space to explore and create, communicate, work cooperatively and constructively by identifying and solving problems (Grosseck, 2009). In the same vein, using web-based educational flashcards increases students' organic chemistry curiosity and the professional chemistry community (Draghici \& Njardarson, 2012). According to Romero et al. (2019) and Rose et al. (2019), students have a positive attitude toward the utilization of web tools in organic chemistry teaching and learning. We therefore concur with Haidar (2014),

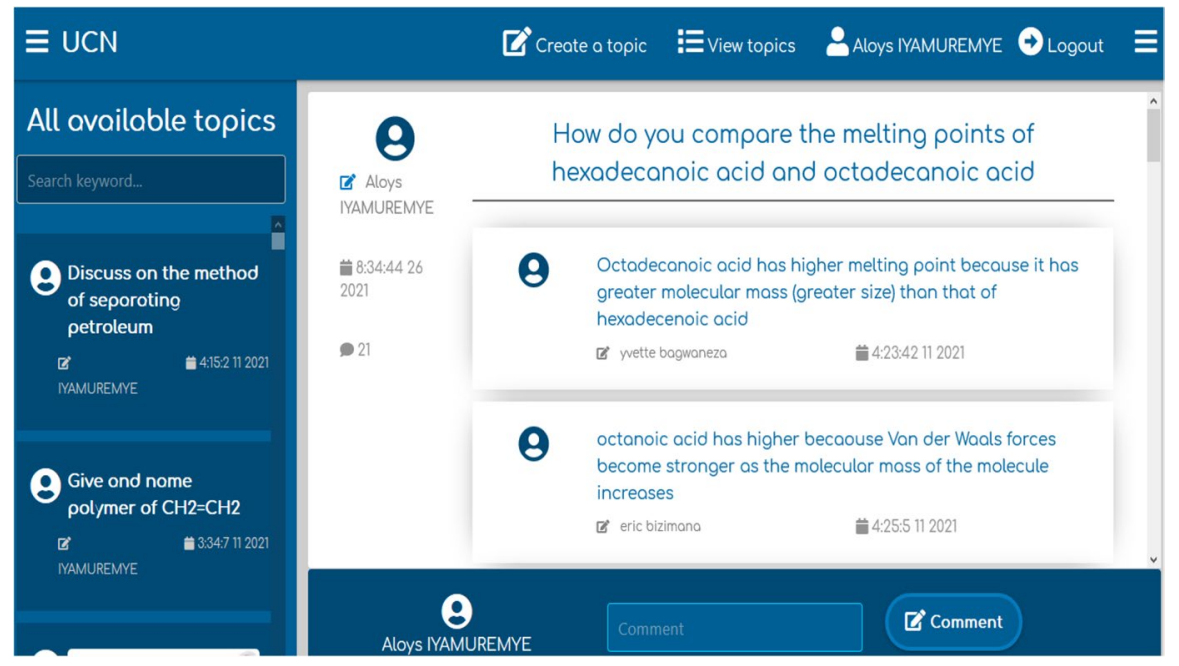

Fig. 4 Discussion room via web-based discussion 
who argued that online discussions provides the greatest tool to students and can provide a space for students and teachers to share knowledge and experiences related to the teaching and learning process.

\subsection{Interaction between students and teaching materials in teaching and learning organic chemistry via WBD}

To explore the interaction of students, researcher, and teaching resources, incorporation of student's ideas was used. During the interview, one student said: “web-based discussion facilitates us to exchange ideas and quality of communications and relationship were improved". Another student stated that "web-based discussion promotes active discussions, participation and excitement and motivation during the discussion." All students reported that web-based discussion is an interesting and interactive platform, which is easy to interact with each other. In addition, the majority of the students (35 out of 40) reported that through the utilization of web-based discussion, the intellectual discourse was increased.

Senior five chemistry teachers also reported their perception on the web-based discussions in teaching and learning, and the letters A, B, C and D were used in order to consider the confidentiality and anonymity of respondents. Chemistry teacher A stated that web-based discussion facilitates exchange of ideas among students and teachers regarding course content and also improved the quality of communications and relationships between students and teachers. Teacher B stated that web-based discussions promote active discussions, participation and excite students' interest and motivation in the subject under study. Teacher $\mathrm{C}$ stated that web-based discussion promotes student-student, student-teacher interactions, and communication in teaching and learning organic chemistry. Teacher D stated that this online forum is interesting and interactive, and it is easy to identify students strengths and weaknesses, and would be useful for helping students based on their understanding.

Those results are in agreement with the previous reported studies. According to Onyema et al. (2019), using online discussion increases students motivation, confidence and free expression of their views and ideas. With reference to Marzano and Ochoa-Siguencia (2017), having access to internet inspires students to show more interest and commitment to class activities. With reference to Romero et al. (2019), web-based discussions are a student-centered approach that increases interaction and practices. Using web-based discussion encourages students to express ideas, share experiences, improve writing skills, and practice grammar and vocabulary (Krasnova \& Ananjev, 2015). Our findings concur with ones found in the other subjects and show how Rwandan teachers are eager to adapt the integration of technology in their teaching routine activities. For instance, physics teachers have appreciated the training offered on the use of PhET simulations and YouTube videos in teaching optics and light phenomena (Ndihokubwayo et al., 2020). 


\subsection{Effectiveness of web-based discussion on students' performance in learning organic chemistry}

This section reports the students' scores in pre-and post-tests. The table below shows descriptive analysis of pre-and post-test, and the test scores were measured out of twenty.

The results in Table 1 show that the mean score was 10.65 with a 2.15 standard deviation (Std) in the pre-test, and increased to 11.63 with a 2.45 standard deviation in the post-test. The maximum mark was 16 in pre-test and increases to 18 in post-test. The minimum score was 5 in pre-test and increased to 6 in the post-test. Furthermore, the paired-samples T-test was used between pre- and post-test scores and found a high statistically significant difference $(\mathrm{df}=137, p=.000)$. Thus, the probability value $(p)$ of difference was found smaller than expected .05 (level of significance at $95 \%$ confidence interval) when degrees of freedom was 137 (difference of independent variables one group of students in our case from 138 total number of students), students gained 0.10 learning, and the effect size (d') of this significance was found to be a medium effect $\left(d^{\prime}=0.43\right)$ (see Table 1). Therefore, the null hypothesis was rejected, and the alternative hypothesis is accepted. Thus, the results showed that there is a statistically significant relationship between student's performance and utilization of web-based discussions in teaching and learning organic chemistry.

Since the pre-test was administered after physical teaching, this statistically significant difference is attributed to the effect of web-based discussion. These results indicate that the application of web-based discussions in teaching and learning is potential and effective for enhancing students' performance in organic chemistry. Inci et al. (2008) also found that after utilization of web-based discussions in teaching and learning of chemistry, the mean score has been increased by 0.65 . Similarly, with reference to Sudha and Amutha (2015), there was a difference in mean scores between the group that used web-based discussion and the group which used normal teaching. We, therefore, concur with Romero et al. (2019), who agreed that the use of web-based instructions potentially increases students' performance. According to Hanson (2017), the use of web-based increases students' performance and the mean score was increased by $16.26 \%$, from $33.9 \%$ of pre-test to $50.16 \%$ of post-test. According to Horowitz et al., (2013) noted that web-based discussion increases students' performance significantly in organic chemistry.

Teachers reported that they acquired positive experience from web-based discussion in their teaching and learning of organic chemistry. Teacher A stated that the utilization of web-based discussions adds value and has a positive impact on teaching and learning organic chemistry because students were connected to the internet. When students did not understand the question, they were able to search it on the internet and compare

Table 1 Descriptive and inferential analysis of the preand post-test scores

\begin{tabular}{llllllll}
\hline & $\mathrm{N}$ & Min & Max & Mean & Std. & $\langle\mathrm{g}\rangle$ & $\mathrm{d}^{\prime}$ \\
\hline Pre-test & 138 & 5 & 16 & 10.65 & 2.15 & 0.10 & 0.43 \\
Post-test & 138 & 6 & 18 & 11.63 & 2.45 & & \\
\hline
\end{tabular}


their answers between them. Teachers B stated that web-based discussion has a positive impact on teaching and learning organic chemistry. He indicated that during utilization of this teaching and learning approach, it is easy to monitor the participation of all students, and he also pointed that it is easy to identify students' weakness and strength so that all students get feedback at the same time. Teacher D stated that during traditional discussions, some students did not participate in the discussion, but by using this method the level of participation is increased because it is easy to identify student work. He also reported that during the web-based discussion, students were more independent and had more resources than they used in normal discussion. In fact, the online discussions provides independent time for students and more resources for them as they are connected to the internet to get information about the subjects from varied sources, and this helped in enriching materials dealt with during discussion (Nordin, 2008). According to Shahrokni and Sadeqjoola (2015) search engines, chat, dictionaries, and email are important aspects of web-based discussion that positively impact teaching and learning. The use of web-based discussion favors students' independent use of time (Pineda, 2012).

Among four senior five chemistry teachers who attended the interview, three of them responded that it was the first time that they were used web-based discussion in their teaching, they also reported that they were used normal group discussion and class discussion in their teaching and learning. One teacher reported that it was not the first time he used web-based discussion in his teaching and learning process. He said that he had used an approach which was similar like this during lockdown when all schools were closed, and school adopted a method of online teaching and learning. All four teachers reported said that they had prior knowledge of using the internet in everyday life. They said that in their everyday teaching, they use the internet for preparing lessons by doing research, chatting with friends, sending and receiving documents, etc. Teachers also reported that having prior knowledge of using the internet had a positive impact on the utilization of web-based discussion in their teaching. It was observed that all teachers had experience and were familiar and had a positive perception toward utilization of web-based discussion in teaching and learning organic chemistry.

The response from teachers were in good agreement with the research conducted by Cahyono and Mutiaraningrum (2015), which showed that internet skills for teachers had positive impact on the quality of teaching and learning, and also pointed that teachers' familiarity and experience on utilization of the internet increases confidence and quality of teaching and learning process. With reference to Kay et al., (2009), teachers confirmed that web-based tools are easy to use, and engage students and promote meaningful learning. Those results were also in agreement with the results from the study conducted by Romero et al. (2019) which found that instructors used the internet, and web 2.0 tools in their daily life showed that it might be acceptable to support instruction for a large group of learners. 


\subsection{Challenges associated with the utilization of web-based discussions in teaching and learning organic chemistry and their potential solutions}

From the interview, students and teachers indicated some challenges associated with using web-based discussion and their potential solutions. Thirty-five students out of forty indicated that they do not have their own and individual computers, insufficient time to access available computers in school computer labs. In addition, twenty-five students out of forty reported that they sometimes fail to post their comments due to low internet connection. All teachers agreed that low technical skills and poor internet connection hinder effective teaching and learning via web-based discussions. Two teachers out of four teachers responded that classroom management is difficult because some students were out of the discussion by doing other things not related with the lesson such as watching video on YouTube and Facebook chatting. Three teachers out four responded that many messages, insufficient time, poor quality of posts were the major problem of utilization of web-based teaching and learning.

The challenges raised by students and teachers in this study were also noted by Onyema et al. (2019), who revealed that factors such as poor electricity, low student/ teacher commitment, delay of feedback, poor quality of postings, time and internet connections limitations were found to be the challenges that limit the success of the online discussions. However, Nsabayezu et al. (2020) argue that students enjoy online discussions even if the internet connection is a barrier that leads to slow communication between teachers and students. Teachers and students have proposed some potential solutions based on their challenges. They propose to provide enough time for access to computer, full internet connection and regular timetable for computer lab. To handle the faced challenges, teachers proposed that providing personal computer for both students and teachers, enough internet connection, training of teachers and students and strong collaboration between parents and education administrators are required.

\section{Conclusion and recommendation}

The present study intended to examine the secondary school teachers' and students' perception on web-based discussions in teaching and learning and its potentiality to enhance students' performance in organic chemistry. The study also investigated the challenges faced by students through the use of web-based discussion while learning chemistry. A scale data analysis using t-test showed a statistically significant influence of web-based discussion on students' performance after learning organic chemistry via web-based discussions. The interview findings showed that students interact with each other and the teacher via web-based discussions and then discuss a given topic. It was also found that students construct their knowledge via social interactions between teachers and students since they can search for additional information, freely exchange their ideas, share knowledge and experiences. This study highlighted some challenges associated with the utilization of web-based discussions, such as the lack of students' personal computers and insufficient internet connections. A further study is needed to cover a big sample of students with a control/ 
treatment pre/post-test design and a follow-up of trained teachers' future use of webbased discussion via the universal chemistry network.

\section{Appendix: Students' performance test for organic chemistry}

Instruction: This test is composed of 20 multiple-choice questions; answer all questions by encircling the best only one answer among four choices, Duration: 1hour

1. What is the IUPAC name of $\mathrm{CH}_{3} \mathrm{CH}_{2} \mathrm{C}\left(\mathrm{CH}_{3}\right)_{2} \mathrm{CH}_{2} \mathrm{CH}\left(\mathrm{CH}_{3}\right)_{2}$ ?
A) 3,3,5-trimethylhexane
B) 2,2,5-trimethylhexane
C) 2,4,4-trimethylhexane
D) 1,1,3,3-tetramethylpentane

2. Which of the following conformational structures is 2-methyl pentane?

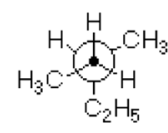

A

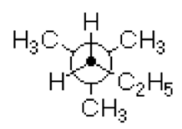

$\mathrm{B}$<smiles>CCCCC</smiles>

$\mathrm{C}$<smiles>CCCCC</smiles>

D

3. There are four constitutional isomers having the formula $\mathrm{C}_{4} \mathrm{H}_{9} \mathrm{Cl}$

Which of the following would be a correct IUPAC name for one of these isomers?
A) 1-chloro-2-methylpropane
B) 3-chlorobutane
C) 2-chloro-2-methyl butane
D) 1-chloro-3-methyl propane

4. Which isomer of hexane has only two different sets of structurally equivalent hydrogen atoms?
A) 2,2-dimethylbutane
B) 2-methylpentane
C) 3-methylpentane
D) 2,3-dimethylbutane 
5. Limiting your answer to cycloalkanes and ignoring stereoisomers, how many constitutional isomers are in $\mathrm{C}_{6} \mathrm{H}_{12}$ ?
A) 6
B) 9
C) 12
D) 13

6. The IUPAC name for $\left(\mathrm{CH}_{3}\right)_{2} \mathrm{CHCH}\left(\mathrm{CH}_{3}\right) \mathrm{CH}_{2} \mathrm{CH}=\mathrm{CH}_{2}$ is ...
A) 4,5-dimethyl-1-hexene
B) 4,5,5-trimethyl-1-pentene
C) 2,3-dimethyl-5-hexene
D) 4-methyl-4-isopropyl-1-butene

7. How many isomers exist in pentene $\left(\mathrm{C}_{5} \mathrm{H}_{10}\right)$ ? (count stereoisomers as well)
A) 4
B) 5
C) 6
D) 7

8. A $_{6} \mathrm{H}_{12}$ compound reacts with ozone to yield a single $\mathrm{C}_{3} \mathrm{H}_{6} \mathrm{O}$ product. Gas-phase free-radical bromination of the hydrocarbon gives a single $\mathrm{C}_{6} \mathrm{H}_{11} \mathrm{Br}$ product. A likely identification of this compound is:
A) Cyclohexane
B) B) cyclohexene
C) 3-hexene
D) 2,3-dimethyl-2-butene

9. The most typical reaction of simple alkenes is:
A) Electrophilic substitution
B) Nucleophilic substitution
C) Electrophilic addition 
D) Nucleophilic addition

10. Which of the following dimethylcyclobutanes is chiral?
A) Trans-1,2-dimethylcyclobutane
B) Cis-1,2-dimethylcyclobutane
C) Trans-1,3-dimethylcyclobutane
D) Cis-1,3-dimethylcyclobutan

11. The radical halogenation of 2-methylpropane gives two products: $\left(\mathrm{CH}_{3}\right)_{2} \mathrm{CHCH}_{2} \mathrm{X}$ (minor) and $\left(\mathrm{CH}_{3}\right)_{3} \mathrm{CX}$ (major). Chlorination gives a larger amount of the minor product than does bromination; why?

A) Bromine is more reactive than chlorine and is able to attack the less reactive $\mathrm{C}-\mathrm{H}$ bond.

B) Bromine atoms are less reactive (more selective) than chlorine and preferentially attack the weaker $\mathrm{C}-\mathrm{H}$ bond.

C) The methyl groups are more hindered to be attacked by the larger bromine atom.

D) Bromination is reversible, and the more stable alkyl bromide is formed exclusively.

12. A tertiary carbocation is more stable than either a secondary or primary carbocation because ....
A) It carries three positive charges
B) It has a pyramidal configuration
C) It has a trigonal planar configuration
D) It possesses three electron-donating substituent groups

13. Which of the following is not an electrophile?
A) $\mathrm{C}_{2} \mathrm{H}_{5} \mathrm{OC}_{2} \mathrm{H}_{5}$
B) $\mathrm{BF}_{3}$
C) $\left[\mathrm{CH}_{3}\right]_{3} \mathrm{C}^{+}$
D) $\mathrm{HOCl}$ 
14. Which of the following olefins would you expect to react most rapidly with concentrated sulphuric acid?
A) $\mathrm{H}_{2} \mathrm{C}=\mathrm{CH}_{2}$
B) $\left(\mathrm{CH}_{3}\right)_{2} \mathrm{C}=\mathrm{CH}_{2}$
C) $\mathrm{Cl}_{2} \mathrm{C}=\mathrm{CCl}_{2}$
D) $\mathrm{CF}_{3} \mathrm{CH}=\mathrm{CH}_{2}$

15. Which compound is more likely product from the addition of $\mathrm{Cl}_{2}$ to 1-butene?
A) $\mathrm{CH}_{3} \mathrm{CH}_{2} \mathrm{CH}_{2} \mathrm{CHCl}_{2}$
B) $\mathrm{CH}_{3} \mathrm{CH}_{2} \mathrm{CHClCH}_{2} \mathrm{Cl}$
C) $\mathrm{ClCH}_{2} \mathrm{CH}_{2} \mathrm{CH}_{2} \mathrm{CH}_{2} \mathrm{Cl}$
D) $\mathrm{CH}_{3} \mathrm{CH}_{2} \mathrm{CCl}_{2} \mathrm{CH}_{3}$

16. The product from bromine addition to trans-2-butene will be ....
A) Optically active
B) Racemic
C) A meso compound
D) Chiral

17. Which of the following alkyl halides would most rapidly undergo SN2 reaction?
A) $\mathrm{CH}_{3} \mathrm{CH}_{2}-\mathrm{Br}$
B) $\mathrm{CH}_{3} \mathrm{CH}_{2}-\mathrm{Cl}$
C) $\mathrm{CH}_{3} \mathrm{CH}_{2}$-I
D) $\mathrm{CH}_{3} \mathrm{CH}_{2}-\mathrm{F}$
E) They react at the same rate

18. The bond dissociation energy is the amount of energy required to break a bond
A. So as to produce the more stable pair of ions
B. Heterolytically
C. Homolytically
D. Via hydrogenation 
E. None of the above

19. Peroxide-induced reaction of carbon tetrachloride with 1-butene produces which of the following product?
A) 1,1,1,3-tetrachloropentane.
B) 1,1,1,2-tetrachloropentane.
C) 1-chloro-2-trichloromethylbutane.
D) 1,1-dichloro-2-ethylcyclopropane.

20. Which of the following isomeric hexenes will have the smallest heat of hydrogenation?
A) 4-methyl-1-pentene.
B) (E)-4-methyl-2-pentene.
C) (Z)-4-methyl-2-pentene.
D) 2-methyl-2-pentene.

Acknowledgement This work was supported by the African Center of Excellence for Innovative Teaching and Learning Mathematics and Science (ACEITLMS), hosted by the University of Rwanda-College of Education (UR-CE).

\section{References}

Ahmad, N., Samara, H., and Academic Development. (2016). "Effectiveness of Analogy Instructional Strategy on Undergraduate Student' s Acquisition of Organic Chemistry Concepts in Mutah" 7 (8): $70-74$

Anderson, T. L., \& Bodner, G. M. (2008). What Can We Do about 'Parker'? A Case Study of a Good Student Who Didn't 'get' Organic Chemistry. Chemistry Education Research and Practice, 9(2), 93-101. https://doi.org/10.1039/b806223b

Bashir, M., Afzal, M. T., \& Azeem, M. (2008). Reliability and Validity of Qualitative and Operational Research Paradigm. Pakistan Journal of Statistics and Operation Research, 4(1), 35. https://doi.org/ 10.18187/pjsor.v4i1.59

Bialik, M., Trilling, B., and Groff, J.S.. (2015). "Skills for the 21 St Century : What Should Students Learn ?," no. July 2017

Cahyono, B. Y., \& Mutiaraningrum, I. (2015). Indonesian EFL Teachers' Familiarity with and Opinion on the Internet-Based Teaching of Writing. English Language Teaching, 9(1), 199. https://doi.org/ 10.5539/elt.v9n1p199

Dogruer, N., Eyyam, R., \& Menevis, I. (2011). The Use of the Internet for Educational Purposes. Procedia - Social and Behavioral Sciences, 28(December), 606-611. https://doi.org/10.1016/j.sbspro. 2011.11.115

Draghici, C., and Njardarson, J.T.. (2012). "Chemistry By Design: A Web-Based Educational Flashcard for Exploring Synthetic Organic Chemistry," no. 3: 1080-82

Epignosis. (2014). "E-Learning Concepts, Trends, Applications." Book, 5 
Ferguson, R., \& Bodner, G. M. (2008). Making Sense of the Arrow-Pushing Formalism among Chemistry Majors Enrolled in Organic Chemistry. Chemistry Education Research and Practice, 9(2), 102113. https://doi.org/10.1039/b806225k

Fraenkel, J. R., Wallen, N. E., \& Hyun, H. H. (2012). How to Design and Evaluate Research in Education (8th ed.). McGraw Hill

Garrison, D.R. (2018). “Communities of Inquiry in Online Learning,” no. January 2009. https://doi.org/ 10.4018/978-1-60566-198-8.ch052

Graham, C.R. (2015). “Full Text Available Online @,” no. May 2016. https://doi.org/10.19173/irrodl. v16i3.2015

Grosseck, G. (2009). To Use or Not to Use Web 2.0 in Higher Education? Procedia - Social and Behavioral Sciences, 1(1), 478-482. https://doi.org/10.1016/j.sbspro.2009.01.087

Haidar, N.H. (2014). "Perceptions of Higher Education Online Learning Faculty in Lebanon,” 151

Hanson, R. (2017). "Enhancing Students ' Performance in Organic Chemistry Through Context- Based Learning and Chemistry Through Context-Based Learning." European Journal of Research and Reflection in Educational Sciences Vol. 5 No. (November): 7-20

Hayashi, P., Abib, G., \& Hoppen, N. (2019). Validity in Qualitative Research: A Processual Approach. Qualitative Report, 24(1), 98-112

Horowitz, G., Rabin, L. A., \& Brodale, D. L. (2013). Improving Student Performance in Organic Chemistry : Help Seeking Behaviors and Prior Chemistry Aptitude. Journal of the Scholarship of Teaching and Learning, 13(3), 120-133

Inci, M., Ural, E., and Temel, S.. (2008). "The Effect of Web-Based Project Applications on Students ' Attitudes towards Chemistry The effect of web-based project applications on students ' attitudes towards chemistry," no. December 2014

Johnstone, A. H. (2000). Teaching of Chemistry - Logical or Psychological? Chem. Educ. Res. Pract., 1(1), 9-15. https://doi.org/10.1039/a9rp90001b

Johnstone, A. H. (2006). Chemical Education Research in Glasgow in Perspective. Chemistry Education Research and Practice, 7(2), 49-63. https://doi.org/10.1039/B5RP90021B

Kay, R., Knaack, L., and Petrarca, D. (2009). "Exploring Teachers Perceptions of Web-Based Learning Tools." Interdisciplinary Journal of E-Skills and Lifelong Learning 5: 027-050. https://doi.org/10. 28945/63

Krasnova, T., \& Ananjev, A. (2015). Students' Perception of Learning in the Online Discussion Environment. Mediterranean Journal of Social Sciences, no., (November). https://doi.org/10.5901/mjss. 2015.v6n6s1p202

Lee, J., Song, H.-d., \& Hong, A. J. (2019). Exploring Factors, and Indicators for Measuring Students. Sustainable Engagement in e-Learning. https://doi.org/10.3390/su11040985

Lorenzo, M.G., Reverdito, A., Blanco, M., and Salerno, A.. (2012). "DIFFICULTIES OF UNDERGRADUATE STUDENTS IN THE ORGANIC CHEMISTRY" 42 (1973): 74-81

Marzano, G., and Ochoa-Siguencia, L. (2017). "Challenges of Web-Based Participatory Learning." SOCIETY. INTEGRATION. EDUCATION. Proceedings of the International Scientific Conference 2 (May): 458. https://doi.org/10.17770/sie2017vol2.2395

Ndihokubwayo, K., Uwamahoro, J., Ndayambaje, I.. (2020). "Usability of Electronic Instructional Tools in the Physics Classroom." EURASIA Journal of Mathematics, Science and Technology Education 16 (11): 1-10. https://doi.org/10.29333/ejmste/8549

Fariza, N., Razak, N. A., \& Aziz, J. (2010). E-Learning: Analysis of Online Discussion Forums in Promoting Knowledge Construction through Collaborative Learning. WSEAS Transactions on Communications, 9(1), 53-62

Nordin, A.B.. (2008). "Web-Based Teaching And Learning Approach ( WBTLA ) Usability In Institutions Of Higher Learning In" 1: 44-55

Nsabayezu, E, Iyamuremye, A., Kwitonda, J.D., and Mbonyiryivuze, A.. (2020). "Teachers 'Perceptions towards the Utilization of WhatsApp in Supporting Teaching and Learning of Chemistry during COVID-19 Pandemic in Rwandan Secondary Schools" 16 (2)

Nsengimana, T., Nyirahabimana, A., \& Nsengimana, V. (2021). Online Learning during COVID-19 Pandemic in Rwanda : Experience of Postgraduate Students on Language of Instruction. Mathematics and Science Education, 2(1), 1-7

O’Dwyer, A., \& Childs, P. E. (2017). Who Says Organic Chemistry Is Difficult? Exploring Perspectives and Perceptions. Eurasia Journal of Mathematics, Science and Technology Education, 13(7), 35993620. https://doi.org/10.12973/eurasia.2017.00748a 
Ochonogor, C.E.. (2020). "Assessment of undergraduate chemistry students ' difficulties assessment of undergraduate chemistry students ' Difficulties in organic chemistry," no. September

Onyema, E. M., Deborah, E. C., Alsayed, A. O., Noorulhasan, Q., \& Sanober, S. (2019). Online Discussion Forum as a Tool for Interactive Learning and Communication. International Journal of Recent Technology and Engineering, 8(4), 4852-4859. https://doi.org/10.35940/ijrte.d8062.118419

Pineda, J. E. (2012). EFL Students' Perceptions about a Web-Based English Reading Comprehension Course. Profile Issues in Teachers`Professional Development, 14(2), 113-129

Poon, W. C., Low, K. L. T., \& Yong, D. G. F. (2004). A Study of Web-Based Learning (WBL) Environment in Malaysia. International Journal of Educational Management, 18(6), 374-385. https://doi. org/10.1108/09513540410554031

REB. (2015a). Comptence-Based Curriculum. Curriculum Framework Pre-Primary to Upper Secondary. http://reb.rw/fileadmin/competence_based_curriculum/syllabi/curriculum_framework_final_ printed.compressed.pdf. Accessed 24 Jan 2021

REB. (2019). Subject based teacher training manual on competence-based curriculum, Science and Elementary Technology (SET) no. July. https://elearning.reb.rw/pluginfile.php/39439/mod_resource/ content/2/1.pdf. Accessed 24 Jan 2021

Romero, R.M., Vidal Espinosa, L.O., Vidal Espinosa, L.O., and Hernández, D.R.. (2019). “Organic Chemistry Basic Concepts Teaching in Students of Large Groups at Higher Education and Web 2 . 0 Tools Darinka Ramírez Hernández Organic Chemistry Basic Concepts Teaching in Students of Large Groups at Higher Education and Web 2 . 0 Tools," 0-31. https://doi.org/10.15517/aie.v19i1. 35589

Rose, J., Pennington, R., Behmke, D., Kerven, D., Lutz, R., Barker Paredes, J.E., Georgia Gwinnett College, and United States. (2019). "Maximizing Student Engagement Outside the Classroom with Organic Synthesis Videos.” https://doi.org/10.1021/acs.jchemed.9b00234

Rushton, G. T., Hardy, R. C., Gwaltney, K. P., \& Lewis, S. E. (2008). Alternative Conceptions of Organic Chemistry Topics among Fourth Year Chemistry Students. Chemistry Education Research and Practice, 9(2), 122-130. https://doi.org/10.1039/b806228p

Sanderson, B., \& Field, J. (2018). Introduction of an Online Discussion Forum and Electronic Communication Practice in a Tertiary-Level Anaesthesia Department. Journal of Hospital Administration, 7(6), 24. https://doi.org/10.5430/jha.v7n6p24

Shahrokni, S. A., \& Sadeqjoola, L. (2015). Iranian EFL Teachers' Perception, Familiarity and Use of Web 2.0 Tools in TEFL. Teaching English with Technology, 15(3), 31-46

Shana, Z.. (2015). "Learning with Technology : Using Discussion Forums to Augment a TraditionalStyle Class Learning with Technology : Using Discussion Forums to Augment a Traditional-Style Class," no. August

Starks, H.. (2008). "Qualitative Health Research," no. January. https://doi.org/10.1177/1049732307 307031

Sudha, A, and Amutha, S. (2015). "Higher Secondary Learners ' Effectiveness towards Web Based Instruction ( WBI ) on Chemistry" 3 (7): 463-66. https://doi.org/10.13189/ujer.2015.030706

Tomasello, M. (2016). Cultural Learning Redux. Child Development, 87(3), 643-653. https://doi.org/10. 1111/cdev.12499

Umurerwa, A. (2016). "The State of E-Learning in Rwanda"

Uwamahoro, J., Ndihokubwayo, K., Ralph, M., \& Ndayambaje, I. (2021). Physics Students' Conceptual Understanding of Geometric Optics: Revisited Analysis. Journal of Science Education and Technology, 30(0123456789), 1-13. https://doi.org/10.1007/s10956-021-09913-4

Wilkinson, I.A.G. (2016). "Discussion Methods," no. April

Zhou, M., and Brown, D.. (2014). "Educational Learning Theories"

Publisher's note Springer Nature remains neutral with regard to jurisdictional claims in published maps and institutional affiliations. 


\section{Authors and Affiliations}

\section{Aloys lyamuremye ${ }^{1}$ Janvier Mukiza ${ }^{1,2} \cdot$ Ezechiel Nsabayezu $^{1}$. Fidele Ukobizaba ${ }^{1} \cdot$ Kizito Ndihokubwayo $^{1}$}

Aloys Iyamuremye

aloysiyamuremye@gmail.com

Ezechiel Nsabayezu

ezechielnsabayezu109@gmail.com

Fidele Ukobizaba

ukobifidele@gmail.com

Kizito Ndihokubwayo

ndihokubwayokizito@gmail.com

1 African Center for Innovative Teaching and Learning Mathematics and Science (ACEITLMS), Rukara, Rwanda

2 School of Education, College of Education, University of Rwanda, Rukara, Rwanda 